\title{
A SOCIAL-SCIENTIFIC READING OF THE PARABLE OF THE SHREWD STEWARD IN LUKE 16:1-9 IN A CONTEXT OF CORRUPTION
}

\author{
Dogara Turrang Silas \\ Department Old and New Testament \\ Stellenbosch University
}

\begin{abstract}
Understanding the parables of Jesus is difficult, complicated, and sometimes controversial. In the case of the parable of the shrewd steward, this is particularly true. The parable as recorded in Luke 16:1-9 has for many years been a source of bewilderment and confusion for scholars (Combrink 1996:286; Kloppenborg 1989:474). Ford (2000:10) and Herzog (1994:233) state that, of all the parables that are accredited to Jesus, it is generally held to be among the most difficult to comprehend. In the words of Scott (1989:255), "[t]his master's praise for his unjust steward has created confusion, controversy, and embarrassment in the interpretation of the parable", for how could the master praise the servant for such an unjust act $?^{2}$ The master's praise is especially problematic in the social, political, cultural and economic context of the author of this article (Nigeria), where corruption is no longer seen as a vice but as a virtue. The question is, how can the parable, which seems to encourage dishonesty, be read, and understood in a context of corruption? It is this question this paper will attempt to answer.
\end{abstract}

Keywords: Social-scientific; Parable; Steward; Luke 16:19; Corruption

\section{Previous interpretations}

The parable in question is perhaps the strangest and the most baffling of all the parables of Jesus. Preachers are hardly ever heard to preach about this parable. On this note, numerous attempts have been made in the past to interpret the parable of the shrewd steward, of which the following are the most common.

Snodgrass (2008:406-407) states that the parable of the shrewd steward is often read allegorically as an argument for giving alms. This interpretation of the parable appeals to its readers to give as much as possible to gain an eternal dwelling in the world to come. Zimmermann (2015:37), who traced the history of allegorical interpretation of the parables in the New Testament, including the parable in question, indicates that in the history of research, researchers have come to the conclusion that many interpretations in practice can be considered to be what Julicher ${ }^{3}$ characterizes as "allegorizing".

\footnotetext{
Parabole was the Greek term for an illustration, a comparison, or an analogy, usually in story form, using common events of daily life to teach or reveal a moral or spiritual truth (Anderson 2013:65).

2 Reinstorf (2013:3-4) enumerates other instances in the Lucan text in which Jesus used questionable characters (e.g. the parable of the good Samaritan (10:25-37) and the parable of the tax collector (18:9-14)) and states that the use of such characters by Jesus in the Gospel of Luke is not unusual.

3 Julicher is known to be one of the most influential parable scholars of the $20^{\text {th }}$ century.
} 
Secondly, it is understood that it is the steward's wisdom, particularly his wisdom in using money, and not his acts of dishonesty, that is praised. This suggests that one way to solve the problem posed by the parable condoning dishonesty, is to see the master's praise not as an affirmation of his wrongdoing, but as approval of the steward's wise conduct in a crisis (see Reid 2000:194; Schumacher 2012:275). This line of interpretation does not deny the dishonest act of the steward; it stresses that this is not what is praised, but rather his shrewdness.

Closely connected to the abovementioned interpretation, is the suggestion that the steward earned his master's favour by deducting either unlawful penalties, or his own commission, from the debts owed to the master (Stein 1981:108-109). In view of this, the steward's dishonest acts can be viewed as legal, since the charging of interest, legally forbidden by the Torah (Deut 23:19-20), was now remitted by him. This line of interpretation, of taking the steward as acting in a financially responsible manner, is unsatisfactory, since the reason given for his remittance of the debts of the debtors in the parable is his laziness and fear, and not his respect for the Torah.

Another interpretation is that the steward's actions, as deceitful as they were, nevertheless, are worthy of praise because he gained public appreciation for his master. The question of what is at stake for the master in a situation in which others tell him that his steward is squandering his property is, however, not as obvious as may first appear. While most modern readers simply assume that the owner is upset by the decrease in the value of his assets, caused either by the failure of the steward to earn a sufficiently high return on his investments, or by the steward's misappropriation of the master's funds for personal gain, the master may have a different understanding of what transpired (Landry and May 2000:298). The social status and honour of a male head of a household, like the rich man in the parable under consideration, was tied to power, which was understood in the ancient world as the ability to exercise control over the behaviour of others. It was not only a matter of having control over employees, but also about being in control of one's affairs. Therefore, having a steward who squandered his property would make the master dishonourable among his peers, as the master would have been seen to not be able to control his affairs.

Moreover, a person's honour is not limited to how they judge themselves, but also depends on recognition of and how the community judges the person (Yu Yap 2016:208). On this note, while the action of the manager may have been wrong, the master's praise may be seen as an effort to protect his social status.

One may thus argue that, while the steward's actions were unrighteous in the eyes of both the master and Jesus, he might have received praise specifically for his inspired attempt to find a new home. However, the passage does not distinguish between the steward's foresight and the ethical nature of the actions performed. Furthermore, if the steward's actions were indeed fraudulent, then it is unlikely that he would have successfully found a new home (or future employment) with the master's debtors, since they would have every reason to believe that the steward would commit similar crimes against them.

\section{A social-scientific reading of Luke 16:1-9}

While the above interpretations may have both strong and weak points, this article suggests the reading of the parable in Luke 16:1-9 using a social-scientific approach. The 
need to consider the social values of the world it originated in, is necessary, since the meaning of the parable in question arises in the interaction between the narrated elements and the cultural anthropology that the parable deliberately suggests (Kloppenborg 1989:486-487). In approaching the evaluation of the parable from this perspective, this article builds primarily on the work of Herzog, Combrink and Scott, who all use a similar approach to interpreting the parable in question. However, reference will be made to the work of other scholars where appropriate.

\section{The social context of Luke 16:1-9}

According to Elliott (1993:10): “... New Testament writings ... are hardly devoid of social detail ...”. In the light of this, one may agree with Neyrey and Stewart (2008: xxii) that "words take their meaning from a social system, not from a lexicon". The social world, or the social system of the $1^{\text {st }}$ century in which the text in question was produced, therefore needs to be examined to provide an appropriate cultural and social background against which the ancient texts can be read on their own terms. ${ }^{4}$ The patterns of behaviour they describe, likewise constitute the social context (the environment involving a plurality of persons and groups), which is shaped by socio-economic and societal conditions, structures and processes. In their language, content, structure, strategies and meaning, these texts presuppose, encode and communicate information about the systems in which they were produced and to which they were a response (Elliott 1993:9-10). Understanding the text in question in the light of its social context, is therefore vital and justifiable.

Building on the work of Combrink (1996), who only focuses on honour as a pivotal value, the elements of social values to be discussed here include the culture of honour and shame, the patron-client relationship, benefaction, hospitality in the ancient Mediterranean world, and the economic ${ }^{5}$ world of the $1^{\text {st }}$ century. The inclusion of benefaction and hospitality is suggested by Kloppenborg (1989:491), in that the act of reducing the size of debts by the steward, was an act of benefaction. In the moral and political economy of antiquity, this act imposed an obligation on the recipients and made the steward a patron of his master's debtors. In view of this, the expectation was that he might be received into their households, which suggests hospitality. ${ }^{6}$

\section{A culture of honour and shame}

The concepts of honour and shame exist in almost all cultures. However, in many contemporary Western societies, these terms play a minor role as social values. Many people in these cultures today regard "honour" as an old-fashioned word, while they normally associate the term "shame" with the most private aspects of their lives (Moxnes

\footnotetext{
4 Zimmermann (2015:31), who suggest three perspectives for understanding the parables of Jesus - a historical, literary and reader-oriented approach - comments on the historical approach, saying that the parables arose in a particular time and cultural space and are part of a history and tradition that need to be taken into consideration in their interpretation.

5 Giving the picture of the socio-economic system, Kim (1998:252) and Oakman (2008:63) state that the $1^{\text {st }}$ century period was characterised by extreme inequality and peasant indebtedness. The rich and the powerful were likely to become richer and mightier owing to their political power and social status, while the poor and helpless were vulnerable to forces that could render them poorer and more helpless, owing to their existing disadvantages.

6 Baergen (2006:27) suggests that the parable must also be read within the context of ancient slavery.
} 
1996:19). In both past and present Mediterranean societies, however, honour and shame played and continue to play an important role in public life. As a pivotal value ${ }^{7}$ in the ancient Mediterranean world, honour stood for and determined a person's rightful place in society. The place of honour was determined by boundaries consisting of power, sexual status, and position on the social ladder (Plevnik 2000:106).

Honour has to do with the value people have in their own eyes and in the estimation of others in their social group (Malina 2001:52; Neyrey 2008:88). Honour is thus not honour unless it is publicly claimed, displayed, and acknowledged - in other words, it is fundamentally the public recognition of one's social standing. Honour operates in two ways: one's basic honour, usually termed "ascribed honour", is honour inherited from one's family at birth, while honour conferred based on virtuous deeds is called "acquired honour". The latter is a kind of honour that has to be worked for by way of a struggle for recognition, and may be either gained or lost (Moxnes 1996:20). In view of this, Yu Yap (2016:209) also explains how goods, including honour, existed in limited amounts in the ancient Mediterranean society. Those who wanted to improve their social standing in society, had to do so at the expense of others. So, one person's claim to honour could be understood as a threat to the honour of others.

In the ancient world, one's honour was also related to one's gender, which generally reflected the power structures in ancient Mediterranean society. As those who dominated the public sphere, men were set on defending their masculinity. To earn his honour, a man had to be able to defend the chastity of women under his dominance and protection. Should a woman lose her chastity, it implied shame for the family (Moxnes 1996:21). Honour could not only be lost, but could also be earned. One could also gain honour at the expense of others' honour through competition and challenge (Downing 2007:884).

Women, on the other hand, were potential sources of shame. However, in the Mediterranean culture, for many shames had a positive side, as it was related to modesty, shyness or deference. These were regarded as virtues - often construed as feminine virtues - that enabled a woman to preserve her chastity as well as her obedience to the male head of her family (Moxnes 1996:21). According to Downing (2007:884), women were thus seen as vulnerable, and liable to forfeit their men's honour by their own shameful acts. In another sense, shame was simply being socially sensitive and was thus applied to both men and women. So, to be shameless was, for example, to lack concern for one's honour and to be insensitive to the opinions of others.

\section{Patron-client relationship and benefaction}

Evidence from the $1^{\text {st }}$-century period abundantly attests to the existence of a Roman social institution known as "clientela or, in modern terms, patronage and clientage" (Elliott 1996:144). This important and persistent form of dependency relations, involving the reciprocal exchange of goods and services between socially superior patrons and their socially inferior clients, shaped both the public and private sectors of ancient life, as well as the political and religious symbolisation of power and dependency (Elliott 1996:144). A patron-client relationship was a social, institutional arrangement by means of which economic, political, or religious institutional relationships were operational with the

The word "value" describes some general quality and direction of life that human beings are expected to embody in their behaviour (Plevnik 2000:xv). 
overarching quality of kingship. A patron is like a father, and clients are like loving and grateful children, no matter what their age. Patronage relations permeated the whole of ancient Mediterranean society (Malina 2000:151-153). Batten (2008:47) agrees, stating that patronage was a ubiquitous social framework in the ancient Mediterranean basin. Patrons, on the one hand, were people with power who could provide goods and services not available to their clients. In return, clients provided loyalty and honour to patrons. However, as far as the principle of reciprocity is concerned, patrons and clients needed each other and benefited mutually from this relationship (Speckman 2007:157). This social institution of patronage was also common in the days of Jesus, as is evident in Luke $7: 2-5.8$

Though benefaction is similar to patronage, they also seem to differ, in that benefaction has a clear lack of self-interest on the part of the provider. Whereas a patron sought clients and an increased honour rating, a benefactor gave in order to help people without consideration of the honour that it would bring to them (Batten 2008:47). A benefactor, moreover, was not necessarily superior to those to whom they gave benefactions and gave primarily to help the community (city), and not only specific clients (individuals) (Speckman 2007:159). There are, however, a few similarities between benefaction and patronage. The language of friendship common to patronage language, for example, is also used of benefactors, as is the language of fatherhood, which is especially characteristic of such individuals (Batten 2008:47).

\section{Hospitality in the ancient Mediterranean world}

The practice of receiving a guest or a stranger graciously was very common throughout the period in which the Old and the New Testament were composed (Koenig 1992:299). This played an important role in both tribal and domestic life. Existence in a desert made it a necessity, and among the nomads it become a highly esteemed virtue. Through hospitality, foreigners or weary travellers found rest, food and shelter, and asylum. This custom was supported by the thought that the host himself might one day be a guest (Funderburk 2009:229-230). One may say that this process of receiving outsiders and changing them from strangers to guests, was a value that served as a means for attaining and preserving honour. Thus, it justifies the intention of the steward in question.

\section{Social-scientific reading of Luke 16:1-9}

The first character introduced in this parable is an unnamed rich man who had a steward 9 (v. 1b). All stories draw on a range of social expectations, cultural conventions and so

This system could be likened to what I refer to in this paper as godfatherism/motherism; or a system of give and take; or even, you don't get something for nothing.

9 According to White (2009:609), the English word "steward" (oikovó $\mu$ ○ ) can be used to render the Hebrew noun soken (Is 22:15), but more commonly translates as a Hebrew phrase involving a relative pronoun, preposition, and the noun bayit (house). For example, Joseph's steward (Gen 43:19) represents the Hebrew ha is aser al bet yosep ("the man who was upon the house of Joseph"). In the New Testament, the word appears seven times besides in Luke 16 - once again in Luke (12:42), four times in the Pauline epistles (Rom 16:23; 1 Cor 4:1, 2; Gal 4:1), once in Titus 1:7, and once in 1 Peter 4:10. The term is used to describe a steward, (epitropos), which denotes "a guardian" or "a manager" (Lk 12:42-44, 16:1-2). The King James Version uses the word "steward" with some frequency to render two Greek nouns, epitropos, meaning "manager" or "foreman" (Mt 20:8), and oikonomos, meaning "household manager" or "administrator" (Lk 12:42). In view of 
forth, that make a narrative lifelike (Scott 1989:260). ${ }^{10}$ The first line of the parable draws from the social range of the patron-client model, in which a rich man and a steward represent values that were familiar for hearers at the time. It casts the rich master ${ }^{11}$ in a predetermined role: that of an absentee property owner whose steward manages his estate. As a landowner he might probably have resided in a preindustrial city, so that he employed an estate manager who had the right to rent property, make loans and liquidate debt on his behalf.

However, the master here need not have been, as is often assumed, an absentee landlord making one of his infrequent visits to check up on his affairs. Resident landowners could also entrust their affairs to stewards and would be more likely to receive such a "tip-off" (Nolland 1993:797). But whether the master in the parable, as pointed out above, was an absentee landlord who only visited his estates on occasion, or a member of the local nobility who lived closer to his estate, perhaps in a nearby urban centre, one thing is certain - he was clearly part of the elite class, since in the parable he

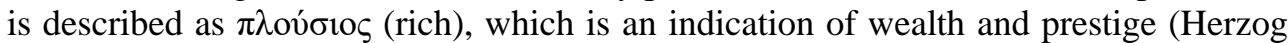
1994:240). As a rich man, he would have had some economic and political influence. ${ }^{12}$

The fact that the steward's negligence or dishonesty was known publicly (v. 1c) would thus result in the reputation of the master being damaged. As a result, there was a need for the master to take the necessary action to avoid further loss of his honour. $\mathrm{He}$ could, however, not go to the court, as this would have further damaged his honour, because only those of equal social standing could be challenged in a public setting like a court (Combrink 1996:301). This implies that it was the social standing of the rich man, rather than his money, that was at stake. It also suggests that, if the rumour about the steward's mismanagement had come from within his household, the master would just have punished the steward. But the rumour had come from outside his household, so it was not the steward who was on trial, but rather the master himself - in the court of public opinion among his peers. He would have been considered as one who failed to control and command the respect of his steward, and thus would have incurred grave

this, I agree with Herzog (1994:243) and Jones (2009:379) that a steward in the $1^{\text {st }}$-century world was a manager in a position of considerable authority who managed the affairs of a large household. Thus, like the one mentioned in Luke 16, one can assume that a steward was highly placed in the household administration of the rich and powerful elite, occupying a position between the poor and the rich landowner he served.

10 Combrink (1996:300) and Herzog (1994:239-240) point out that the most common assumption regarding the scene in the parable is that it represents small-village life.

11 The identity of the kurios at the conclusion of the parable in v. 8a remains an issue that has not been resolved satisfactory (Baergen 2006:27; Schellenberg 2008:264). Scholars like De Silva (1993:263), Ireland (1989:300) and Schellenberg (2008:265) refer to him as Jesus, and Schellenberg (2008:265) in particular states that the master (ó кúplo $\varsigma$ ) in v. 8 cannot represent a master who is both wealthy and sympathetic toward the steward's compassionate scheme. Goodrich (2012:550-551), who responds to the view of Schellenberg, states that he fails to acknowledge the implicit examples of benevolent rich men that can be identified in Luke-Acts. For example, in the parable of the prodigal son, which has similarities to Luke 16:1-9, there is an apparently wealthy father who is nothing if not charitable to his irresponsible son. Goodrich is therefore of the opinion that other Lukan parables do portray wealthy kúpıo as generously rewarding their faithful slaves. Thus, the master who is praised in v. 8 cannot be taken as referring to Jesus.

12 However, in Luke the rich are not viewed in a positive light. De Silva (1993:258), who compares the rich man with other occurrences of the rich in Luke, asserts that all those depicted as rich in Luke are, in one form or another, excluded from the redeemed community or disapproved of, with the single exception of Zaccheus, whose salvation comes when he ceases to be notably plousion, giving away more than half of his possessions. 
social stigma (Kloppenborg 1989:489). Therefore, the master had to do something and called on the steward to give an account of his stewardship.

The way in which the rich man responded to the accusation ${ }^{13}$ made against the steward aligned with that of the accusers, and he thus lived up to the social expectation of his time. The rich man's action toward the steward confirms that the story reflected the world of the lower classes. There was no trial; instead, the story jumps immediately to punishment. The steward had no opportunity to explain himself or the action of which he had been accused. He knew neither his accusers nor what their accusations were, except that he had supposedly squandered the master's property (Scott 1989:262). According to Malina and Rohrbaugh (1992:374), traditional Israelite law ruled that an agent was expected to pay for any loss incurred by his employer for which he was responsible. Alternatively, the agent could be put in prison so that the funds could be extorted from his family. However, since neither of the two were applied, one may conclude that the rich man in the parable was not an Israelite.

The steward's response also stresses the hazardous position of the steward. His stewardship was to be taken away from him. Therefore, he said to himself ( $\varepsilon \hat{\imath} \pi \varepsilon v \delta \dot{\varepsilon} \dot{\varepsilon} v$

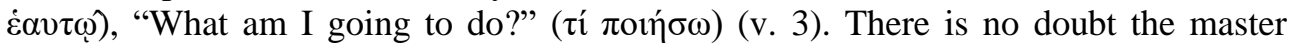
intended the steward to be stripped of his authority to act at once. He had been asked to hand over to his master the documents relating to his conduct of the affairs of his stewardship (Nolland 1993:797). But since it would take time for the news of the steward's loss of his position to reach the master's debtors, there would inevitably be a period that would allow the implementation of the plan that the steward had in mind (Herzog 1994:243). The steward knew that a defence of his actions would not persuade his master to reinstate him, and that if he was to save himself, something needed to be done and done quickly (Kloppenborg 1989:490). The reaction of the steward also implies the validity of the accusation levelled against him.

Combrink (1996:301), Herzog (1994:41) and Scott (1989:263) state that, when the steward contemplated his future if he were dismissed from his stewardship, he envisioned the bleak alternatives of begging or digging, which were the common activities of day labourers (v. 3d). The steward did not contemplate a demotion to the household hierarchy of slaves, or even think of being sold to the mines or galley ships, because he was not a slave. He saw only one way out, which represented a radical departure from the behaviour and principles a steward was expected to exhibit, and set to work enacting it (Combrink 1996:301-302). What is clear, is that the steward rejected any plan of action that would require him to depend only on himself and his strength. He refused to throw himself into the system of almsgiving, depending on others' munificence without any contribution of his own. This also helps reveal the real nature of the steward, which might have been the reason he squandered the resources of his master (i.e. he only served his own interests).

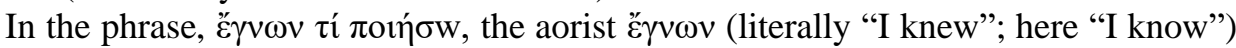
(vv. 4-7) $)^{14}$ paints a picture of the newly acquired knowledge of the steward. He appeared

13 The Greek word used here for accused (dieblethe) is a morpheme of diabolos (devil). "Was accused" is generally used in a hostile sense, at times with the implication of slander (Scott 1989:262).

14 Vv. 4-7 in full read: "I know what I'll do so that, when I lose my job here, people will welcome me into their houses. So, he called in each one of his master's debtors. He asked the first, 'How much do you owe my master?' 
to be complying with the master's demand that he returns the account books of his stewardship, but his symbolic compliance depended on his feigned ignorance of the master's judgment. Instead, he planned to use his master's books to secure a future for himself. The steward recognised that his conduct had resulted in losing his stewardship, so he turned his attention to a new strategy. He intended to make his plans for building a relationship with others by trading material capital for relational debt.

The play upon oikos in the balanced phrases "out of the stewardship" and "in their houses", derives its sense from the fact that the loss of the man's stewardship also entailed the loss of a roof over his head (Nolland 1993:798). The term $\mu \varepsilon \tau \alpha \sigma \tau \alpha \theta \tilde{\omega}$ (when I am expelled) and $\delta \dot{\varepsilon} \xi \omega v \tau \alpha$ í (they will receive me) may refer explicitly to the steward and to the debtors' ${ }^{15}$ homes. It may, however, also refer to judgement in a broader sense. The steward's impending exclusion was very real, and the image of being turned out is also closely related to the image of being cast out in other parables, such as those of the great banquet or the sheep and the goats (Lk 14:15-24). There is also the correlative of being welcome or received into the community of the blessed (Mt 25:14-23). Therefore, the threat of being turned out of his master's house, and the desperate hope of being welcomed into their homes, regulated the steward's thought. The disgraced steward decided to create his own patronal relationship with his master's debtors by reducing their debts. He did that with the intention that they, in turn, would reciprocate his benefaction by showing him hospitality. The basis for his confidence lies in the reciprocity ethic that was so important in the culture of the $1^{\text {st }}$ century.

The major problem in this parable that has been troubling its interpreters, is the master's praise for the unjust steward ("And the master praised the unjust steward for he acted prudently", v. 8a). There is no doubt in terms of the reading of the parable up to now, that a steward who had acted unjustly by wasting his master's properties or possessions, and who, after he had been informed of his dismissal, took a decision to further defraud his master, is praised in the parable as having acted prudently or shrewdly. This creates tension within the narrative and presents the master in a negative light. The plot's logic indeed demands punishment and not praise. This is also challenging in my context (Nigeria), where corruption is a way of life.

Having realised the kindness of the master in not putting him in prison, but instead asking him to put the account of his stewardship in order without demanding repayment, the steward depended on the same reaction in the system he put into motion. According to Malina and Rohrbaugh (1992:37), it is ultimately this arrangement that placed the master in an unusual bind that, if the master overturned the steward's action, the master may in turn have risked a backlash in the village, where the villagers would already have been rejoicing about his surprising open-handedness. However, if the master consented that the reductions should stand, he would be celebrated as an honourable and generous man by those lower down on the economic scale. One could also say that the steward

'Eight hundred gallons of olive oil', he replied. The manager told him, 'Take your bill, sit quickly, and make it four hundred'. Then he asked the second, 'And how much do you owe?' 'A thousand bushels of wheat', he replied. He told him, 'Take your bill and make it eight hundred'.' (NIV).

15 The view commonly held by many scholars is that the debtors in the parable were peasant tenants or sharecroppers who tilled the ground in their master's field and maintained his orchards (Herzog 1994:247). The tenants were probably peasant farmers who had lost their land through heavy indebtedness. As such they would have been living barely above the subsistence level, due to all the taxes they had to pay. So, the reduction of their debts by the steward could have relieved them of their burden in a material sense. 
counted on the latter; that he knew that the master would prefer to be honoured by the tenants than to recover his money. If the master insisted on getting his money back, his honour would have been damaged by public mockery.

Again, the parable does not only recommend the unjust steward, but also encourages the audience to emulate the steward by using their earthly resources to make friends for themselves on earth so that, when all is gone, they will be received into the eternal dwelling (v. 9). Just like v. 8, this verse has also generated mixed feelings on what really should be emulated. Could the parable be taken to encourage dishonest behaviour among its hearers? And how can this be understood in my context, where corruption is seen as a virtue?

Scholars like Ireland (1989:299-300) and Mathewson (1995:38) consider v. 9 as a fitting application of the parable and as a call for resolute action in the face of crisis. According to Mathewson (1995:38), Jesus' "disciples are to use their material possessions and money for spiritual purposes as wisely as the worldly people do for material aims". Ireland (1989:299-300) says that,

[i]nstead of an exhortation for disciples to use their possessions with eternity in view, the parable is viewed in more general terms as a call for resolute action in the face of the eschatological crisis caused by the coming (present, imminent, and/or future) of the Kingdom of God.

It is therefore important to briefly investigate Luke's understanding of wealth and possession, the Kingdom of God, and stewardship.

\section{Wealth and possession and the Kingdom of God in the Gospel of Luke}

According to Ireland (1989:315), Luke 16:1-19 is about the correct use of wealth and possessions. The following occurrences in Luke 16:1-13 and its immediate context are significant in this regard. The word "mammon" occurs in vv. 9, 11 and 13; Luke comments that the Pharisees were lovers of money in v. 14; while the parable of the rich man and Lazarus in vv. 19-31 illustrates the dire consequences of serving mammon. Ireland (1989:315) says the parable of the shrewd steward also implies that the positive course of action (exhorted in v. 9) includes care for the poor. Therefore, it seems clear that Luke 16:1-9 is about the prudent use of one's possessions, and this should be reflected in the interpretation of the parable in both its immediate and broader literary context. ${ }^{16}$

The Gospel of Luke has a clear focus on the poor and the marginalised. In it, Jesus' attitude, actions, and teachings constantly warn that the poor are being abused and neglected (Woodbridge and Semmelink 2014:59). Luke is also fond of challenging the rich in his community on their attitude toward material possessions. In the travel narrative ${ }^{17}$ his view of wealth and possessions is made clear by parables such as that of the rich fool (Lk 12:13-21), the great feast (Lk 14:15-32), the unjust steward (Lk 16:113) and the rich man and Lazarus (Lk 16:19-31). Through Jesus' teachings on the right

\footnotetext{
16 The gospel writer set the parables in a particular context, ranging from the immediate to the broad; each of those contexts can play an important role in elucidating the meaning of the parable in question (Ireland 1992:1-2).

17 Luke 9:51-19:27, Jesus' journey from Galilee to Jerusalem.
} 
use of wealth and possessions, Luke teaches the total renunciation of goods as the cost of discipleship on the one hand, and on the other hand encourages the good stewardship of wealth and possessions (Reinstorf 2002:1288).

In most of the parables of Jesus, a glimpse is given of his view of the centrality of proper stewardship of possessions. Even the parable of the good Samaritan (Lk 10:2737 ) has the main point that love of one's neighbour means being ready and willing to help others in a material and physical predicament (Lk 10:37) (Kim 1998:177). The parable of the great banquet (Lk 14:12-24) indicates a profound gulf between the rich and the poor in the Lukan community ${ }^{18}$ in that, although both shared the same faith, the rich still conducted themselves according to the customs of their contemporary culture, in which the reciprocity system of relationships was the predominant one. The parable of the rich man and Lazarus (Lk 16:19-31) therefore serves as a warning that, in the coming Kingdom of God, the rich and the poor will experience a role reversal. This warning corresponds with that given to the rich in Luke 6:24-25. It also demonstrates a continuity in Luke's concern for the poor, and his warning to the rich of the reversal of fortune in the coming age, which is also found in the Magnificat (Lk 1:53), and woes to the rich (Lk 6:24-26) are unavoidable.

The prudent use of possessions demanded by Luke 16:1-9 is both proof of one's citizenship of the Kingdom of God, and the actualisation of the values of the kingdom in expectation of its final manifestation (Ireland 1992:189). In the Gospel of Luke, Jesus viewed the kingdom as a profound force that resulted in demons being cast out, the sick being healed, lepers being cleansed, and the dead being raised. The relationship between the Kingdom of God and Jesus' ministry is clear from the outset. In Luke 4:16-31, Jesus enacted and performed the Kingdom of God (Chilton 2008:522).

The standard expected by the kingdom can best be seen in the command to love God and others ( $\mathrm{Lk}$ 10:25-37; 6:27-36). Love manifests in the kingdom and gives clear evidence of one's membership of it (Lk 6:35-36, 6:20). Charity is the kingdom behaviour expected of those anticipating the arrival of the coming age. If salvation means God ending the oppression his people are going through (Lk 4:18), then God's people must stop oppressing their fellow human beings (Lk 3:12-14); if it means an end to hunger and want, God's people must share what they have with those who are hungry and naked (Lk 3:11). When such behaviour was demonstrated by the disciples, it gave a picture of how the kingdom had begun to be realised. And thus, it is this standard of living that Luke set for us in Luke 16:1-9.

18 The term 'Lukan community' is a contentious one. Allison (1988:66), who acknowledges the difficulties surrounding the term, states that "... the third gospel and the Acts of the Apostle give every impression of having been written without much special concern for some 'Lukan Community"'. Moxnes (1994:387) suggests that "we can envisage Luke's community as a group of non-elite persons who are culturally and ethnically mixed but who also include among them some who come from the elite periphery". It is difficult to be more specific than Moxnes' description of the community for which Luke was written. 


\section{Appropriation to the Nigeria context: Corruption ${ }^{19}$ in Nigeria and the understanding of Luke 16:1-9}

Corruption has always been a challenge in every society. In the Nigeria context, the situation is worse, because corruption has become the norm. It was thus no exaggeration when Nigerian president Mahammadu Bahari said, "If Nigeria does not kill corruption, corruption will sooner or later kill Nigeria." ${ }^{21}$ It is public knowledge that Nigeria has been assessed as having very high levels of corruption. In Nigeria today, corruption has become so common a word that its actual meaning does not demand any further explanation to an ordinary Nigerian citizen (Anazodo, Ibeto and Nkah 2015:47). One can hardly read a Nigerian national daily newspaper without coming across a page devoted to corruption or on which corruption is mentioned (Vanguard 21 February 2018). Paradoxically, the scourge of corruption has left a country like Nigeria, endowed with enormous natural resources, straddling two economic worlds at the same time. Thus, Nigeria has found itself in the predicament of a country too rich to be poor and, at the same time, too poor to be rich. It is hard to think of any social ill in Nigerian society that is not traceable to embezzlement and the misappropriation of funds and resources (Ikharehon and Omoregie 2015:100; Salisu 2000/2006:3). Corruption takes different forms. But bribery, godfatherism/motherism ${ }^{22}$ and the embezzlement of public funds for personal gain are the most common ones. Corruption is found in every nook and cranny of the Nigeria society. Both lower- and upper-class officials of the Nigeria government are guilty of corruption, and the church, which is supposed to speak against this disease, is not free of it. One would be right to say that dishonest and corrupt leaders, like the steward in Luke 16:1-9, have made Nigeria poor. Achebe (1984:1) supports this by attributing the problem in Nigeria to the failure of leadership. According to him, there is nothing wrong with the Nigerian land, climate, water, air, or anything else. The Nigerian problem is the unwillingness of its leaders to take up the challenge of being an example in their leadership roles. In the midst of this reality, how can the parable of the shrewd steward, which appears to condone and encourage dishonesty, be understood in the context of corruption like that in Nigeria?

19 Politically, corruption "encompasses abuse by government officials such as embezzlement and cronyism, as well as abuses linking public and private actors such as bribery, extortion, influence peddling, and fraud, to mention but a few. In this regard, corruption threatens good governance, sustainable development, democratic process, and fair business practices" (Ogbeidi 2012:5). Ikharehon and Omoregie (2015:97) also provide references to corruption that are relevant to this topic which include diversion and misappropriation of funds through manipulation or falsification of financial records. I believe this is like the actions of the steward in the parable.

20 African, and specifically Nigerian, scholars and pastors have also taken notice of the interpretive challenge posed by the parable of the shrewd steward. They agree with the conclusion of other scholars surveyed in this study that the parable is the most difficult of all the parables of Jesus, as "incompetence, dishonesty, and corruption seem to be rewarded". They believe, however, that the story embedded in the parable, when read in its literary context, is not about dishonesty, but about prudence (Isaak 2006:1236). They state that the task for us today is to have the shrewdness of the steward to understand our context and to wisely make use of any opportunity that exists in the midst of danger, and to use our resources wisely for the benefit of the poor (Isaak 2006:1236; Nicodemus 2015:1, 4).

21 News 24. 2018-07-06 07:34. Available online: https://www.news24.com/Africa/News/nigeria-tightens-screwon-corruption-with-new-order-20180705.

22 By godfatherism and godmotherism, I mean a system in which one gets something based on who you have or who you know. 
One can indeed say that the application (appropriation) of this parable to Nigerian society ${ }^{23}$ should be considered as justifiable, since it presents an important aspect of the Gospel of Luke's ethics on the proper use of wealth and possessions for the sake of the poor in his own community as noted above. Reading the parable within its immediate and broader literary context has provided us with vital information on how to be faithful stewards. To be a faithful steward, is to keep the coming judgement of God and the needs of the poor in view. It is clear that the Lukan Jesus is not encouraging dishonesty, but rather promoting the way the steward in Luke 16:1-9 acted in his moment of crisis in preparing for his future by relieving the poor of their debt burden. These two aspects responding appropriately to the coming judgement and doing so particularly in relation to the use of possessions for the poor - cannot be separated from each other in Luke. Luke, in other words, not only emphasises a general urgency in view of the coming judgement, but also stresses care for the poor.

\section{Conclusion}

To conclude, though the reading of the parable within its social context, and in line with the model of honour and shame, did not provide a reason for the master's commendation, reading the parable within its immediate and broader literary context has provided insight into its potential meaning and is thus applicable to the Nigerian society. Nigerians, and especially the rich Christians from all levels of society, should note the way Luke challenged the rich in his community to manage their resources for the care of the poor. But, just as the parable of the sower (Mt 13:1-9) does not teach readers to follow certain farming practices and the parable of the workers in the vineyard (Mt 20:1-16) does not teach the reader how to pay workers, Luke 16:1-9 does not provide the reader with an excuse for corrupt practices. Rather, these parables only teach readers, especially the rich in Nigeria, how to respond to the coming Kingdom of God. It intends to teach Nigerians (rich Christians) how to live in the light of the coming Kingdom of God, and to focus on the needs of the poor and the glory (honour) of God. In the Nigeria society, which has a lot in common with the context of the Lukan gospel in terms of its high rate of poverty caused by corruption, ${ }^{24}$ the rich should thus be challenged by the shrewdness of the steward to use their wealth and possessions wisely for the benefit of the poor in their society.

\section{BIBLIOGRAPHY}

Achebe, C. 1984. The trouble with Nigeria. Oxford: Heinemann Educational Publishers.

Allison, D.C. 1988. Was there a Lukan community? Irish Biblical Studies 10(2):62-70.

Anazodo, R.O. Ibeto, I.C.J. and Nkah, B.C. 2015. Leadership, corruption, and governance in Nigeria: Issues and categorical imperative, Africa Research Review

\footnotetext{
23 Especially to the rich Christians in Nigeria, since this this parable was addressed to the disciples of Jesus (Yu Yap 2016:2015).

24 Ononoghu, Ossai, Nche and Ibenwa (2016:381) underscore the fact that socio-economic life in the Roman Empire was similar to the present socio-economic state of Nigeria.
} 
9(2):37. Available online: http://dx.doi.org/10.4314/afrrev.v9i2.4 (Accessed 20 October 2015).

Baergen, R.A. 2006. Servant, managers or slave? Reading the parable of the rich man and steward (Luke 12:1-8a) through the lens of the ancient slavery, Studies in Religion/Science Religieuses 35(1):25-38.

Batten, A. 2008. The patron-client institution: God in the letter of James: Patron or benefactor. In J.H. Neyrey and E.C. Stewart (eds), The social world of the New Testament. Peabody, Massachusetts: Hendrickson Publishers, 47-61.

Chilton, B. 2008. Kingdom of God, Kingdom of heaven. In K.D. Sakenfeld (ed.), The new interpreter's dictionary of the Bible (I-Ma), vol. 3. Nashville: Abingdon Press, 512-523.

Combrink, H.J.B. 1996. A social scientific perspective on the parable of the unjust steward (Luke 16:1-18), Neotestamentica 30(2):281-306.

De Silva, D.A. 1993. The parable of the prudent steward and its Lucan context, Criswell Theological Review 6(2):255-288.

Downing, F.G. 2007. Honour. In K.D. Sakenfeld (ed.), The new interpreter's dictionary of the Bible (D-H), vol. 2. Nashville: Abingdon Press, 884-885.

Elliott, J.H. 1993. What is social-scientific criticism? Minneapolis: Fortress Press.

Elliott, J.H. 1996. Patronage and clientage. In R.L. Rohrbaugh (ed.), The social sciences and the New Testament interpretation. Peabody: Hendrickson Publishers, 144-156.

Ford, Q.R. 2000. The parables of Jesus: Recovering the art of listening. Minneapolis: Fortress Press.

Funderburk, G.B. 2009. Hospitality. In M.C. Tenney (ed.), The Zondervan encyclopaedia of the Bible. Grand Rapids: Zondervan, 229-230.

Goodrich, J.K. 2012. Voluntary debt remission and the parable of the unjust steward, Journal of Biblical Literature 131(3):547-566.

Herzog II, W.R. 1994. Parables as subversive speech: Jesus as pedagogue of the oppressed. Louisville: Westminster/John Knox Press.

Ikharehon, J.I. and Omoregie, N. 2015. Corruption and poverty challenges in Nigeria, Indian Journal of Commerce \& Management Studies VI (1):96-102. Available online: www.scholarshub.net (Accessed 20 October 2015).

Ireland, D.J. 1992. Stewardship and the Kingdom of God: An historical, exegetical, and contextual study of the parable of the unjust steward in Luke 16:1-13. Leiden: E.J. Brill.

Isaak, P.K. 2006. Luke. In T. Adeyemo (ed.), Africa Bible commentary: A one-volume commentary written by 70 African scholars. Nairobi: WordAlive Publishers, $1203-1250$.

Jones, C. 2009. Steward, stewardship. In K.D. Sakenfeld (ed.), The new interpreter's dictionary of the Bible (S-Z), vol. 5. Nashville: Abingdon Press, 379.

Kim, K.J. 1998. Stewardship and almsgiving in Luke's theology. Sheffield: Sheffield Academic Press.

Kloppenborg, J.S. 1989. The dishonoured master (Luke 16:1-8a), Biblica 70(4):474495.

Koenig, J. 1992. Hospitality. In D.N. Freedman (ed.), The Anchor Bible dictionary (HJ), vol. 3. New York: Doubleday, 299-301. 
Landry, D. and May, B. 2000. Honor restored: New light on the parable of the prudent steward, Journal of Biblical Literature 119(2):287-309.

Malina, B.J. 2000. Patronage. In B.J. Malina and J.J. Pilch (eds), Handbook of Biblical social values. Peabody: Hendrickson Publishers, 151-155.

Malina, B.J. 2001. The New Testament world: Insight from cultural anthropology. Atlanta: John Knox Press.

Malina, B.J. and Rohrbaugh R.L. 1992. Social-science commentary on the synoptic Gospel. Minneapolis: Fortress Press.

Mathewson, D.L. 1995. The parable of the unjust steward (Luke 16:1-13): A reexamination of the traditional view in light of recent challenges, Journal of the Evangelical Theological Society 30(1):29-39.

Moxnes, H. 1994. The social context of Luke's community, Interpretation: A Journal of Bible and Theology 48(4):379-389.

Moxnes, H. 1996. Honor and shame. In R.L. Rohrbaugh (ed.), The social sciences and New Testament interpretation. Peabody: Hendrickson Publishers, 19-41.

Neyrey, J.H. 2008. Honour and shame: Loss of wealth, loss of family, loss of honour: The cultural context of the original Makarisms in Q. In J.H. Neyrey and E.C. Stewart (eds), The social world of the New Testament. Peabody: Hendrickson Publishers, 85-102.

Neyrey, J.H. and Stewart, E.C. 2008. Preface. In J.H. Neyrey and E.C. Stewart (eds), The social world of the New Testament: Insight and models. Peabody: Hendrickson Publishers, xxi-xxiv.

Nicodemus, P.D. 2015. Prudent stewardship of God's provision, Luke 16:1-13. Unpublished sermon, ECWA Kastit Kafanchan, Kaduna, 30 August 2015.

Nolland, J. 1993. Luke 9:21-18:34. In D.A. Hubbard (ed.), Word Biblical commentary. Dallas: Word Books Publishers.

Oakman, D.E. 2008. Economics: Jesus and agrarian Palestine: The factor of debt. In J.H. Neyrey and E.C. Stewart (eds), The social world of the New Testament. Peabody: Hendrickson Publishers, 63-82.

Ogbeidi, M.M. 2012. Political leadership and corruption in Nigeria since 1960: A socio-economic analysis, Journal of Nigeria Studies 1(2):1-26. Available online: http://www.unh.edu/nigerianstudies/articles/Issue2/Political_leadership.pdf (Accessed 20 October 2015).

Ononoghu, D., Ossai, E., Nche, G.C. and Ibenwa C.N. 2016. Poverty and the poor in the Early Church: A challenge to prosperity preachers in Nigeria, Mediterranean Journal of Social Science 17(5):376-386.

Plevnik, 2000. Honour and shame. In B.J. Malina and John J. Pilch (eds), Handbook of Biblical social values. Peabody: Hendrickson Publishers, 106-115.

Reid, B.E. 2000. Year C parables for preachers. Collegeville: The Liturgical Press.

Reinstorf, D. 2002. Luke's parables and the purpose of Luke's Gospel, HTS Theological Studies 58(3):1281-1295.

Reinstorf, D.H. 2013. The parable of the shrewd manager (Luke 16:1-8): A biography of Jesus and a lesson on mercy, HTS Theological Studies 69(1):1-7.

Salisu, M. 2000/2006. Corruption in Nigeria. Unpublished article, Lancaster University Management School, 1-25. 
Schellenberg, R.S. 2008. Which master? Who's steward? Metalepsis and lordship in the parable of the prudent steward (Luke 16:1-13), Journal for the Study of the New Testament 30(3):263-288.

Schumacher, R.D. 2012. Servant, manager or slave? Reading the parable of the rich man and his steward (Luke 16:1-8a) through the lens of ancient slavery, Review and Exposition 109:269-276.

Scott, B.B. 1989. Hear then the parables: A commentary on the parables of Jesus. Minneapolis: Fortress Press.

Snodgrass, K.R. 2008. Stories with intent: A comprehensive guide to the parables of Jesus. Grand Rapids: W.B. Eerdmans Publishing Company.

Speckman, M.T. 2007. A Biblical vision for Africa's development? Pietermaritzburg: Cluster.

Stein, R.H. 1981. An introduction to the parables of Jesus. Philadelphia: The Westminster Press.

Vanguard. February 21, 2018, 11:28 pm. Corruption is getting worse in Nigeria Transparency International. Available online: https://www.vanguardngr.com/2018/02/21 corruption-getting-worse-Nigeriatransparency-international/.

White, W. Jr. 2009. Steward. In M. Tenney (ed.), The Zondervan encyclopaedia of the Bible (Q-Z), vol. 5. Grand Rapids: Zondervan, 609.

Woodbridge, N. and Semmelink, W. 2014. Wealth and poverty in Luke's gospel and Acts in terms of Brewer's analysis and its challenge for today's church, Conspectus 18:59-78.

Yu Yap, M. 2016. Three parables of Jesus through the shame-honor lens, AJPS 12(2):207-223.

Zimmermann, R. 2015. The puzzling parables of Jesus: Methods and interpretation. Minneapolis: Fortress Press. 